\title{
ROLE OF THE CUSTOMER VALUE IN THE SOFTWARE AS A SERVICE CONCEPT
}

Empirical evaluation of the factors affecting the customer lock-in of the online newspapers

\author{
Markku Sääksjärvi, Aki Lassila \\ Department of Business Technology, Helsinki School of Economics, P.O. Box 1210, \\ FIN-00101, Helsinki, Finland; E-mail: saaks@hkkk.fi, aki.lassila@iki.fi
}

\begin{abstract}
According to evolving literature on the Software as a Service (SaaS) concept, the benefits proposed for the customer and the provider are controversial as many of the customer benefits are also serious risks for the service provider. A sustainable service in the proposed one-to-many SaaS-mode will therefore require an effective business model capable to lock-in customers. For this purpose we propose applying general e-commerce business models. To tailor these for SaaS, we need to develop new instruments in order to study the customer benefits and value creation. For our explorative empirical study we propose that ease of use and usefulness from the Technology Acceptance Model (TAM) should be combined with content, context, and infrastructure from Rayport and Sviokla's model in order to study the evolution of the lockin of the customers of online services. Our empirical data on 251 online newspaper readers showed that the above-mentioned predictors appeared in new factorial combinations of navigational characteristics, usefulness, novelty of the content, complementarities, and the context of the service. These combinations were significant predictors of the customer lock-in, many of them being competitive. For the experienced customers, personally relevant and useful content and effective infrastructure explained over 40 percent of the variance in the lock-in. For the non-experienced users the novelty of the services was the most significant predictor of the lock-in. We discuss the role of the customer value sources (novelty, effectiveness, and complementarities) for practical development of the online Software as a Service offering.
\end{abstract}

Key words: Software as a Service; online newspapers; e-commerce; value creation; customer lock-in. 


\section{INTRODUCTION: WHAT CONSTITUTES SAAS?}

The Software as a Service (SaaS) is a rather new and still somewhat ambiguous concept. Origins of the SaaS model can be traced back to the time-sharing services and one of the latest manifestations of the SaaS is the Application Service Provisioning (ASP) model. Originally, an IDC White paper (IDC, 1999) defined the following criteria for the ASP: it is 1) application centric, 2) only application access (not ownership) providing, 3) centrally managed, and 4) one-to-many service, that 5) is delivered on the contract. In this original ASP concept the customer could, besides remote usage of application software, purchase application support, and also rent the required data center infrastructure capacity. The ASP concept was offered as a new and competitive form of remotely hosted and outsourced application service for the customers.

In the late 1990s, many industry analysts forecasted explosive growth for the ASP market. So far, early studies on the success of ASP companies have shown only a modest rate of success (e.g. Desai and Currie 2003; Cherry Tree 2000). More recently, both significant ICT market analysts and software industry organizations have presented an improved and extended version of the ASP model, called "Software as a Service" (Cherry Tree, 2000; SIIA, 2001; Hoch F. et al., 2001; Mizoras and Goepfert, 2003).

A white paper of the Software \& Information Industry Association eBusiness Division (SIIA, 2001) proposed a service initiative as well as introduced the term "Software as a Service". The aim of the paper was to change the perspective from outsourcing to network-based service point-ofview. The general assumption seemed to be that if the customers will get an easy access to valuable software service and the payment is not directly related to the real costs of development, the market will grow and thus the vendor will also benefit. What constituted a "service" was not defined explicitly, but it seemed that one should count the ex-ante application development and implementation plus integration of all the components of the online service infrastructure to accomplish the SaaS offering. This differs from the marketing definition of service, e.g. according to Grönroos et al. (2000) the main characteristic of services is their process nature. Grönroos et al. stated that" from this core characteristic of services follow other characteristics: the consumption of a service takes place simultaneously with the service process and customers participate more or less actively in the service process and by their behavior influence the progress and outcome of the process".

On the basis of our literature study (Sääksjärvi et al., 2005) we propose that the ASP/SaaS literature does not yet react to the fact that the SaaS model, which changes one-to-one (business-to-business) relationships into 
one-to-many relationships, will also transform the market relations and the traditional software licensing model to the one-to-many utility e-commerce model. This will require the creation of a strong brand, either enabling hybrid revenue logic where low priced software offering is still possible or requiring customization and lock-in to justify higher prices for the service. Apparently critical to the success of the SaaS model will be the types of new application and service innovations made. Not much is yet known of the factors that affect SaaS users' interest to begin and continue using these online services.

\subsection{Objectives of the paper}

The purpose of this paper is to apply the four value creation sources of Amit and Zott's e-commerce model (2001) and to carry out an empirical survey of the customer lock-in and its predictors in one special application domain area, the online newspapers. The online papers typically combine free content, special applications, and a variety of complementary services to attract new and retain their old online readers. Our objective is to apply the key factors, ease of use and usefulness, of the well-known Technology Acceptance Model (Davis, 1986), which was originally proposed for the evaluation of behavioral intention to use an IS application in the organizational context. We will combine these factors with a more recent conceptual Rayport and Sviokla's model's factors (1994). The main ingredient of our research is to integrate the items of the above-mentioned two models to improve their predicting power regarding the customer lockin. We think that this is a novel and relevant approach as most of the online newspapers are portals offering content, interactive web-based services, and applications of digital products and services and therefore we can get valuable information of the factors affecting the customer value and behavior.

Earlier explorative work of Lu and Lin (2002) combined the very general Theory of Reasoned Action (TRA) model (Ajzen and Fishbein, 1980) with the Rayport and Sviokla's model and used students as respondents. Since Lu and Lin's work was based on the TRA model and did not integrate e.g. business model or e-commerce aspects into their study, we think that our research study provides more extensive and detailed view on the subject matter.

This paper is structured as follows. In chapter 2 , we discuss briefly the problems that online application services are facing and lay ground for the need to integrate new online marketspace oriented instruments to measure customer value and behavior. In chapter 3 , we describe the research methodology and present our research framework. In chapter 4 , we describe 
our data collection and in chapter 5 we review the results. In the final chapter we conclude our observations and review the main findings and recommendations.

\section{ONLINE NEWSPAPERS AS A TYPE OF SOFTWARE AS A SERVICE}

As the SaaS provider can be a distributor for software applications, it can also be seen as a distributor for data (news, information) by providing access or an interface for the online papers' readers to content. In the Software as a Service model, the service is no longer only just an application provisioning service but integration of valuable application software into the online service infrastructure. We think that the SaaS model should be understood as a typical e-commerce arrangement dealing with digital products. Therefore also the problems associated with digital products e.g. durability, easy copying, experience product characteristics, and difficult price setting (Shapiro and Varian, 1999) should be taken into account. We define the SaaS model as follows (see Sääksjärvi et al., 2005): "Software as a Service is time and location independent online access to a remotely managed server application, that permits concurrent utilization of the same application installation by a large number of independent users (customers, subscribers), offers attractive payment logic compared to the customer value received, and makes a continuous flow of new and innovative software possible".

All in all, these observations make the SaaS model problematic since the entry barrier can be high. The SaaS concept seems realistic only if the online paper (i.e. the SaaS provider) is able to offer immediate and continuous customer value e.g. novelty and efficiency. Even then also customization and/or lock-in is required to make the business sustainable. It is important to note that many of the SaaS benefits are only efficiency based (Amit and Zott, 2001) and conditional, based on the pre-condition that the SaaS provider could overcome the above-mentioned significant risk issues.

\subsection{The e-commerce view}

Amit and Zott's value creation model (2001) is based on the virtual markets "in which business transactions are conducted via open networks based on the fixed and wireless Internet infrastructure". The underlying theoretical models of Amit and Zott's model are the value chain framework (Porter, 1985), Schumpeterian innovation (Schumpeter, 1942), the resourcebased view of the firm (e.g. Wernerfelt, 1984; Barney, 1991), strategic network theory (e.g. Dyer and Singh, 1998; Gulati et al., 2000) and 
transaction cost economics (Williamson, 1975). Amit and Zott's model enables the evaluation of the value creation potential of different business models through four value drivers: efficiency, complementaries, lock-in, and novelty. Amit and Zott (2001) also emphasize the distinction between a business model and a revenue model: the business model primarily refers to value creation whereas the revenue model is centered on value appropriation. By the term "value" they refer to the total value created for all parties involved in the value network that a certain firm's business model compasses.

In the Amit and Zott's model (2001) the most important value driver is efficiency: the greater the transaction efficiency gains are i.e. when the costs per transaction decrease, the more valuable the e-business will be. Efficiency enhancements include e.g. streamlining the virtual value chain (Rayport and Sviokla, 1995) and enabling faster access to a wider range of real-time news. Another source of value creation are complementaries, such as providing online discussion rooms for readers or offering links to related information or news. Online newspapers can also create value by capitalizing on complementaries among activities e.g. when an online paper and a travel agency co-operate and offer discounts on vacation packages for the paper's subscribers.

According to Amit and Zott (2001) the value-creating potential of an online paper's business model also depends on the value driver called lockin, which refers to the online paper's ability to e.g. get readers to renew their subscriptions. Lock-in usually refers to switching costs but in this case it refers to the online paper's readers' loyalty to remain as subscribers. Lock-in includes e.g. loyalty programs (discounts on longer subscriptions), personalization, customized news etc. The fourth value driver, novelty, consists of new ways e.g. of conducting the online business, offering news and articles (read sports news with your mobile phone) or new ways of combining products and services (subscribers of the "offline" paper gain access to the online version of the paper). Usually the four value drivers and their effects are interrelated with one another.

If we compare the value sources of Amit and Zott's general e-commerce model (2001) with the structure of the well-known TAM model, which is used to predict the intention to use an IS, we can see that there are a few interesting similarities from the customer point of view. First of all, the dependent variable of the TAM model, the behavioral intention of the customer to use the system, is one measure of the (mental) lock-in of the customer. The two major predictors of the user lock-in in the TAM model are ease of use and usefulness of the IS in question. When we think about online newspapers as a SaaS offering, both ease of use and efficiency are related to the infrastructure technology. In a typical web-based environment 
ease of use may loose part of its original importance and move closer to the efficiency dimension of the Amit and Zott's model (2001). Usefulness is also related to the novelty of the received content or infrastructure technology, partly due to the fact that usefulness and the value of the content of the online newspaper may be related. Other important sources of the customer value may be found in complementarities such as competitions, archival services, free e-mail etc.

\subsection{The marketspace view}

Rayport and Sviokla (1994) have examined and explained the differences between the physical, real-world marketplace and the virtual marketspace of the Internet. To illustrate their point of how value creation in the marketplace and marketspace differ they proposed a model, which consisted of three elements: content, or what companies are offering; context, or how they are offering it; and infrastructure, what enables the transaction to occur. Rayport and Sviokla emphasized that content in the marketspace may not automatically mean product and that distribution may not automatically refer to physical location. To outline an example of their model, Rayport and Sviokla used an online newspaper to show how content, context and infrastructure could be disaggregated in the marketspace. In the marketspace the content (news, business, sports, weather etc. pieces of information) can be separated from the context (online newspaper) and the infrastructure (network), which cannot be done with an offline newspaper that has its stories (content) printed on paper (context) in a printing press and is available to customers e.g. from newsstands or via postal delivery (infrastructure). This disaggregation of content, context, and infrastructure meant that in the marketspace new ways of adding value, lowering costs, forging relationships with non-traditional partners, and rethinking ownership issues was possible. Rayport and Sviokla also predicted that most newspaper publishers would find themselves competing in a service-focused, rather than product-focused, business. According to them, since managing in the marketspace means combining content, context and infrastructure in new and creative ways it also means that the interaction, or in this case the interface, between the customer and the companies has also changed. This means that the customer loyalty (lock-in) in the marketspace differs from that in the marketplace. The companies can now manage directly their interface and interaction with the customers at different levels. Now the companies can e.g. achieve brand differentiation and increase customer loyalty at different levels. 


\subsection{Research questions}

In order to empirically study the factors that affect the online newspaper's customers' loyalty we formulated a research question following the idea of comparison and integration of the TAM (Davis, 1986) and Rayport and Sviokla's (1994) models for this research study about the online newspapers.

RQ: What are the roles of ease of use, usability, content, context, and infrastructure in predicting the customer lock-in (loyalty) in the case of online newspapers? Are the general e-commerce based value sources (novelty, effectiveness, and complementarities) relevant compared to them?

Our assumption, based on the theories, was that in the case of an online application service the users (at least the more experienced users) are no longer capable to separate the impact of ease of use and usefulness, because they have become parts of the standard Internet infrastructure. This should be seen in the resulting structure of the explorative factor analysis as integrating the single measures of the above models together and also when comparing the predicting power of the regression analyses.

Our empirical survey was carried out in the Finnish newspaper industry setting, which is an interesting market. Finland is one of the globally leading countries regarding the national IT infrastructure available for online services and their usage. Also the population's motivation and possibility to read newspapers on a daily basis are the highest globally (Statistics Finland/Tilastokeskus, 2002).

\section{RESEARCH METHODOLOGY}

We created and pre-tested an online survey questionnaire in cooperation with one of the leading newspaper companies in Finland in order to empirically study the customer value processes and the lock-in (loyalty) of their online newspaper's readers. In the survey instrument, we included the original items used in the earlier TAM studies for usefulness and ease of use, and we also included new items to cope with the content, context, and infrastructure items of the Rayport and Sviokla's model.

Several empirical studies have been published about the TAM model proving the original and modified items of the model to be quite reliable instruments in predicting user behavior (Legris et al., 2003). Originally, Davis (1986) proposed that the mediating role of user (behavioral) attitude was critical as a reliable predictor of the (Behavioral) Intention to use the system (BI). He proposed that two variables have an affect on Attitude (A): perceived Ease Of Use (EOU) and perceived Usefulness (U). In the later 
version of the model, Davis et al. (1989) leaved the attitude (A) item out and applied only intention (BI) as the success measure. We selected both of these measures into our survey to create a new dimension for measuring the mental lock-in (loyalty) of the SaaS customers.

Rayport and Sviokla's model (1994) is a conceptual one, proposing that online service providers should benefit from the new possibilities of both disaggregating content, context and infrastructure and from the renewal of the old value chain. We created new items for measuring the various aspects of the online newspaper's content, context (visual and structural characteristics of a web-site), and infrastructure (technical efficiency).

We finalized and pre-tested the survey questionnaire, which consisted of the above-mentioned items. As external variables we included items identifying the usage of complementary services and the exact demographics of the respondents including their age, gender, education, experience of using online newspapers, number of newspapers they frequently used, and self-evaluation of their level of Internet usage skills.

We did an exploratory factor analysis, which can be seen as a technique to aid in theory building (Sharma, 1996), in order to verify the constructs' reliability for the factor dimensions. To compare the predicting power of the new combined model to the other models, we also factored their items in order to get valid results. These constructs served as independent variables in a series of regression analyses, which were done in order to compare the predicting power of the different combinations of the factor dimensions.

\section{DATA COLLECTION}

\subsection{Sample selection and data collection}

The survey questionnaire was pre-tested and improved in a few interviews with experienced online newspaper readers. We wanted to make sure that all questions were semantically precise and understandable. The names and e-mail addresses of the online newspaper's subscribers were picked out as a random sample of ca. 2500 names from the customer register of the newspaper company. An invitation letter was sent via e-mail to the respondents. The respondents were asked to participate in our study and fill in the questionnaire that was available on the web. After one reminder e-mail message we had received a total of 251 answers. We eliminated the possibility of getting double answers from one respondent by e.g. checking the $\mathrm{IP}$ addresses on the received responses. All in all, the response rate was ca. 10 percent. This is quite typical and acceptable in most web-based surveys, provided that all measures will be confirmed by factor analyses and 
also by splitting the data. In addition, the demographics of the respondents did not differ from the general profile of the registered customers and therefore the respondents represented well the selected newspaper's online customers.

\subsection{Demographics of the respondents}

The respondent sample was quite smoothly distributed among all age groups between 20 and 60 years. The respondents represented many different professions; typically they (over 40 percent) were white-collar office workers, one third of the whole population having a higher academic degree. However, there were a lot less female than male online readers among the respondents: only 26 percent of the answerers were women. As many as 78 percent of the respondents classified themselves as experienced Internet users, ca. 60 percent of all respondents having over four year experience of reading online newspapers. These online readers also had experience from several other online newspaper services as well: typically, the respondents were reading several (maximum of seven) online newspapers and were using a variety of complementary services. The number of complementary services used seemed to be related with the reader's experience of using the online newspaper. The typical palette of complementary services consisted of the news services, special theme pages, archival services, and the weather forecast service. These were all used at least by one third of all the readers of the online newspaper.

\section{RESULTS}

\subsection{Factor Analysis}

The dimensions representing the new structural combinations of the factors perceived by the online readers are shown below (see details in Table 1). We named these six factor dimensions as follows (they are listed in the order of their eigenvalues, which are in parenthesis):

1. Navigational characteristics, F1-EASYNAVI (9.115)

2. Personal relevancy of content, F2-CONTVALUE $(2.287)$

3. Attractiveness of context, F3-CONTEXT (1.445)

4. Usefulness of complementarities, F4-COMPLEM (1.109)

5. Playfulness, F5-PLAY (1.106)

6. Free offerings, F6-FREE (1.011) 
These six factors together explained 73 percent of the total variance. Interestingly, the strongest factor, Navigational characteristic (F1), was composed of the typical TAM-based usability items, and also Attractiveness of content (F3) was related with the structural part of the usability. The second factor (F2-CONTVALUE) was composed of three content based, two usefulness related and two infrastructure items. This combination was a good example of the fusion of usefulness (meaningful for me), content (good, broad coverage of the topics), and efficiency (website that was fast and effective to use). Factor F3 could be seen as structural and visual usability oriented dimension presenting issues, which are important in the new context of an online newspaper. Therefore, we named it as "Attractiveness of context".

The rest of the factors were weaker, not as stable as the first three when the data was split into two parts e.g. on the basis of the experience of the users. Interestingly, the Usefulness of complementarities factor (F4) integrated usability, content, and coverage items regarding complementary services. The last two factors, Playfulness (F5) and Free offerings (F6), were statistically weak. Leaving them out from the analysis did not change the remaining factor structure.

When we took only the less-experienced users (half of the sample) into the analysis, the factor structure slightly changed as one additional factor appeared in the structure. Three vague usefulness items that had to be dropped from the earlier factor structure formed a new factor called Novelty (F7), which consisted of characteristics such as "unique, up-to-date, and freshness" of the services.

Figure 1. The combined factor structure of the customer lock-in $(\mathrm{N}=251)$

\begin{tabular}{llllll}
\hline Factor & $\begin{array}{l}\text { Factor } \\
\text { loadings }\end{array}$ & Mean & $\begin{array}{l}\text { Std. } \\
\text { Dev. }\end{array}$ & $\begin{array}{l}\text { Items } \\
\text { correlation } \\
\text { with total } \\
\text { score }\end{array}$ & $\begin{array}{l}\text { Eigenval } \\
\text { \% of var }\end{array}$ \\
\hline CUSTOMER LOCK-IN & & & & & $\begin{array}{l}\mathbf{4 . 0 7 2} \\
\mathbf{( 5 8 . 2 \% )}\end{array}$ \\
A-01 Likes to use & 0.729 & 4.63 & 1.000 & $0.688^{* *}$ & \\
A-02 Positive attitude toward usage & 0.678 & 4.97 & 0.870 & $0.635^{* *}$ & \\
A-04 Favourite web-site & 0.790 & 3.02 & 1.600 & $0.800^{* *}$ & \\
BI-01 Intention to continue usage & 0.830 & 4.11 & 1.350 & $0.832^{* *}$ & \\
BI-02 Intention to recommend & 0.831 & 4.22 & 1.230 & $0.814^{* *}$ & \\
BI-03 Intention to use frequently & 0.784 & 3.78 & 1.550 & $0.794^{* *}$ & \\
BI-04 Intention to bookmark & 0.679 & 4.25 & 1.840 & $0.734^{* *}$ & \\
\hline
\end{tabular}

** Correlation is significant at the 0.01 level

The dependent variable of our study, the customer lock-in, is described in Figure 1. We combined items representing the attitude (current satisfaction 
and positive attitude towards the online usage) and intention (motivation to continue the usage) to result in only one factor representing the (mental) lock-in of the readers. This variable, the Customer lock-in (loyalty), was used as the dependent variable in the following regression analyses.

\begin{tabular}{ll} 
Figure 2. Correlation coefficients between the key variables \\
\hline Independent & Combined lock-in \\
variables/models & (Attitude and Behavioral Intention) \\
\hline F1-EASYNAVI & $0.455^{* *}$ \\
F2-CONTVALUE & $0.650^{* *}$ \\
F3-CONTEXT & $0.459^{* *}$ \\
F4-COMPLEM & $0.489^{* *}$ \\
F5-PLAY & $0.154^{*}$ \\
F6-FREE & $0.298^{* *}$ \\
(F7 NOVELTY) & $\left(0.612^{* *}\right)$ \\
& \\
TAM-Usefulness U & $0.686^{* *}$ \\
TAM-Structural EOU (F3) & $0.459^{* *}$ \\
R-S-Content\&Infra & $0.604^{* *}$ \\
R-S-Context & $0.459^{* *}$ \\
\hline ** Correlation is significant at the 0.01 level \\
* Correlation is significant at the 0.05 level
\end{tabular}

\subsection{Results from the regression analyses}

The correlation coefficients in Figure 2 demonstrate that the new integrated factor construct F2 (Personal relevancy of content) and the TAMbased usefulness $(U)$ factor had somewhat higher correlation with the lock-in than the other factors. Accordingly, these two were the most significant single predictors of the lock-in. However, also the marketspace oriented factor Rayport and Sviokla's Content\&Infra and the interesting Novelty (F7) factor had high (over 0.6 ) correlations. In addition, both usability measures (F1 and F3) were important predictors of the lock-in; however they had lower correlation with the lock-in (level 0.4 ). When determining the best combined regression models it turned out that the co-correlations between the factors typically eliminated the effects of the second and third predictors. We could conclude that the new combined measures were competitors (mediators, not moderators) of the two models used.

Furthermore, Playfulness (F6) explained less than $10 \%$ of the variance in the dependent variable. This is not surprising since the playfulness consisted of light entertainment and gossip columns, neither of which seemed to be high on the online newspapers' readers list of topics of interest.

From Figure 3, we can see the results of our comparison between the best three regression models, based on the three sets of the best predictors. The results show that the new combined constructs F2, F7, and F4 explained 48.7 
percent of the variance of the lock-in. The other two sets of predictors also achieved a good $\mathrm{R}^{2}$ values: TAM $43 \%$ and Rayport-Sviokla $38 \%$.

Figure 3. Comparison of the regression models

\begin{tabular}{cccc}
\hline Model (dependent variable in parenthesis) & $\mathrm{R}^{2}$ & Beta & Significance \\
\hline TAM model (Behavioural Intention, BI) & & & \\
Usefulness (U) & $41.6 \%$ & 0.647 & 0.000 \\
Usefulness (U) + F1-EASYNAVI & $43.0 \%$ & 0.145 & 0.009 \\
Rayport-Sviokla model (Customer Lock-in) & & & \\
Content (CON) + Infra (INF) & $36.3 \%$ & 0.604 & 0.000 \\
Content + Infra + Context (F3) & $38.0 \%$ & 0.169 & 0.006 \\
Combined model (Customer Lock-in) & & & \\
F2-CONTVALUE & $42.4 \%$ & 0.650 & 0.000 \\
F2 + F7-NOVELTY & $48.0 \%$ & 0.306 & 0.000 \\
F2 + F7 + F4-COMPLEM & $48.7 \%$ & 0.118 & 0.037 \\
\hline
\end{tabular}

When the data was split into subsets of readers according to the primary complementary services they used (whether it was archival, weather forecast, ice-hockey fun club etc.) we noticed some interesting development trends. According to the theory presented, the more experienced readers seemed to increase their palette of services. Broader service palette and more frequent usage of services seemed to improve the customer lock-in, at least to a certain limit (until 5 to 7 different services used).

The practical conclusions from the above results are that the online newspapers' readers seem to be interested not just in reading the news but also in the other additional services that the newspapers are offering. Together these two affect the continued usage of the online service. In order to increase the number of readers (i.e. to attract new readers) the online newspapers should concentrate more on novelty and complementarities and on useful content and effective infrastructure in order to maintain the lock-in of the existing customers.

\section{CONCLUSIONS}

According to the evolving literature on the concept of "Software as a Service" (SaaS), the benefits proposed for the customer and the provider are controversial as many of the customer benefits are also listed as serious risks for the service provider. A sustainable service in the proposed one-to-many SaaS mode will therefore require an effective business model capable to create and maintain the lock-in of the customers. For this purpose we propose the usage of the Amit and Zott's e-commerce model, which is based on four value drivers one of them being the customer lock-in. 
Our empirical data on 251 online newspaper readers showed that the predictors of the lock-in proposed in the earlier studies appeared in new factor constructs of navigational characteristics, personal relevancy of content, attractiveness of context, and usefulness of complementarities. The navigational and structural usability of the services were significant factors but they were not as good predictors of the customer lock-in as the new integrated constructs. This indicates that in the SaaS context the web-based interface will make the usability less critical as a separate predictor of lockin. In the online context, customers seem to integrate the effects of infrastructure, content, and usefulness in a new way, and the customer value sources seem to be more complex than in the case of the typical organizational IS.

Based on the above-mentioned observations we argue that the evaluation of the Software as a Service offering could benefit from instruments that combine usability, usefulness, and customer value dimensions. Compared to the application centered TAM model, the typical SaaS context integrates application functionality with the content and the infrastructure efficiency. The e-commerce based value drivers of Amit and Zott's model (2001) seem to be relevant in building customer value attributes that explain the customer lock-in. Our results encourage further research and development of new instruments in order to evaluate the customer lock-in in a more reliable way, taking also the customer value creation sources (efficiency, novelty, and complementarities) into the analysis.

On the basis of our research we propose that a Software as a Service providers should also take into account the typical customer life cycle. Novelty seemed to be important to get the customers involved, however it was not sufficient for maintaining a sustainable lock-in. Usefulness (just for me content in an effective format) and a useful set of complementarities were the best predictors in explaining the continued usage of the online services.

\section{REFERENCES}

Amit, R., and Zott, C., 2001, Value creation in e-business, Strat. Management J. 22:493-520.

Ajzen, I., and Fishbein, M., 1980, Understanding attitudes and predicting social behavior, Prentice-Hill, Englewood Cliffs, NJ.

Barney, J. B., 1991, Firm resources and sustained competitive advantage, J. of Management 17:99-120.

Cherry Tree \& Co., 2000, Framing the IT services industry: 2nd generation ASPs, Spotlight Report (September, 2000); www.cherrytreeco.com.

Davis, F. D., 1986, A technology acceptance model for empirically testing new end-user information systems: Theory and results, Doctoral dissertation, Sloan School of Management, MTT. 
Davis, F. D., Bagozzi, R. P., and Warshaw, P. R., 1989, User acceptance of computer technology: A comparison of two theoretical models, Management Science 15(8):9821003.

Desai, B., and Currie, W., 2003, Application service providers: A model in evolution, 5th Intl Conference on E-Commerce (ICEC), Sep 30 - Oct 3, 2003, Pittsburgh, PA, pp. 174-180.

Dyer, J., and Singh, H., 1998, The relational view: Cooperative strategy and sources of interorganizational competitive advantage, Academy of Management Review 23:660-679.

Grönroos, C., Heinonen, F., Isoniemi, K., and Lindholm, M., 2000, The NetOffer model: A case example from the virtual marketspace, Management Decision 38(4):242-252.

Gulati, R., Nohria, N., and Zaheer, A., 2000, Strategic networks, Strat. Mgmt J. 21:203-215.

Hoch, F. et al., 2001, Software as a service: "A to Z" for ISVs, Software \& Information Industry Association (SIIA), Washington, D.C.; http://www.siia.com.

IDC, 1999, The ASPs' impact on the IT industry: An IDC-wide opinion, IDC Bulletin No. 20323.

Legris, P., Ingham, J., and Collerette, P., 2003, Why do people use information technology? A critical review of the technology acceptance model, Information and Management 40:191204.

Lu, H. and Lin, J.C-C., 2002, Predicting customer behaviour in the marketspace: A study of Rayport and Sviokla's framework, Information and Management 40:1-10.

Mizoras, A., and Goepfert, J., 2003, 2003 AppSourcing taxonomy and research guide, IDC Industry Developments and Models (February, 2003) IDC No. 28473.

Porter, M., 1985, Competitive advantage: Creating and sustaining superior performance, Free Press, New York, NY.

Rayport, J. F., and Sviokla, J., 1994, Managing in the marketspace, Harvard Business Review (November-December, 1994), pp. 141-150.

Rayport, J. F., and Sviokla, J., 1995, Exploiting the virtual value chain, Harvard Business Review (November-December, 1995), pp. 75-85.

Schumpeter, J. A., 1942, Capitalism, socialism and democracy, Harper, New York, NY.

Shapiro, C., and Varian, H., 1999, Information rules: A strategic guide to the network economy, Harvard Business School Press, Boston, MA.

Sharma, S., 1996, Applied multivariate results, John Wiley \& Sons, New York, NY.

SIIA, 2001, Software as a service: Strategic backgrounder, Software \& Information Industry Association (SIIA), Washington, D.C. (February, 2001); http://www.siia.com.

Statistics Finland/Tilastokeskus 2002, http:/statfin.stat.fi/statweb, Päivälehtien levikki 1000 asukasta kohden 1990-1998, Joukkoviestintä markkinat Suomessa ja Euroopassa 1996, Tietotekniikka kotitalouksissa 1990-1999, Tietotekniikan käyttö Suomessa ja EU-maissa 1997 ja 1999, Uusien viestimien käyttö Kevät 1999.

Sääksjärvi, M., Lassila, A., and Nordström, H., 2005, Evaluating the software as a service business model: From CPU time-sharing to online innovation sharing, IADIS International Conference e-Society, Malta (June 27-30, 2005), pp. 177-186.

Wernerfelt, B., 1984, A resource-based view of the firm, Strat. Management J. 5:171-180.

Williamson, O. E., 1975, Markets and hierarchies, analysis and antitrust implications: A study in the economics of internal organization, Free Press, New York, NY. 
Appendix 1

Table 1. Combined Factor Structure $(\mathrm{N}=251)$

\begin{tabular}{|c|c|c|c|c|c|}
\hline Factor & $\begin{array}{l}\text { Factor } \\
\text { loadings }\end{array}$ & Mean & $\begin{array}{l}\text { Std. } \\
\text { Dev. }\end{array}$ & $\begin{array}{l}\text { Items } \\
\text { correlation } \\
\text { with total } \\
\text { score }\end{array}$ & $\begin{array}{l}\text { Eigenval } \\
\% \text { of var }\end{array}$ \\
\hline $\begin{array}{l}\text { F1-EASYNAVI } \\
\text { Navigational characteristics }\end{array}$ & & & & & $\begin{array}{l}9.115 \\
(41.4 \%)\end{array}$ \\
\hline EOU -05 Easy to locate oneself & 0.758 & 4.19 & 1.230 & $0.832 * *$ & \\
\hline EOU -06 Not getting easily lost & 0.844 & 4.40 & 1.180 & $0.883^{* *}$ & \\
\hline EOU -07 Easy to navigate & 0.748 & 4.43 & 1.238 & $0.873 * *$ & \\
\hline EOU -08 Quick and easy to learn & 0.814 & 4.94 & 1.101 & $0.861^{* *}$ & \\
\hline $\begin{array}{l}\text { EOU-09 Easy to relearn usage } \\
\text { F2-CONTVALUE } \\
\text { Personal relevancy of content }\end{array}$ & 0.802 & 4.62 & 1.286 & $0.841^{* *}$ & $\begin{array}{l}2.287 \\
(10.4 \%)\end{array}$ \\
\hline U-01 Personally interesting & 0.588 & 4.50 & 1.122 & $0.672 * *$ & \\
\hline Matches my personal needs & 0.639 & 4.31 & 1.193 & $0.802^{* *}$ & \\
\hline CON-01 Sufficient number of news & 0.840 & 4.26 & 1.322 & $0.830^{* *}$ & \\
\hline CON-02 News are well composed & 0.804 & 4.18 & 1.352 & $0.835^{* *}$ & \\
\hline CON-05 Sufficient coverage of news & 0.763 & 4.32 & 1.104 & $0.818 * *$ & \\
\hline INF-01 Services are fast to use & 0.581 & 4.59 & 1.021 & $0.790 * *$ & \\
\hline $\begin{array}{l}\text { INF-02 Services are effortless to use } \\
\text { F3-CONTEXT } \\
\text { Attractive context }\end{array}$ & 0.606 & 4.45 & 1.128 & $0.816^{* *}$ & $\begin{array}{l}1,445 \\
(6.6 \%)\end{array}$ \\
\hline EOU -01 Visually attractive design & 0.811 & 4.38 & 1.154 & $0.845^{* *}$ & \\
\hline EOU -02 Easy perceivable structure & 0.726 & 4.48 & 1.154 & $0.909 * *$ & \\
\hline $\begin{array}{l}\text { EOU-03 Clear and logical structure } \\
\text { F4-COMPLEM } \\
\text { Usefulness of complementarities }\end{array}$ & 0.708 & 4.45 & 1.121 & $0.898^{* *}$ & $\begin{array}{l}1,109 \\
(5.04 \%)\end{array}$ \\
\hline EOU-10 Usability of complements & 0.548 & 4.16 & 1.199 & $0.805^{* *}$ & \\
\hline U-06 Importance of complements & 0.721 & 4.35 & 1.496 & $0.819^{* *}$ & \\
\hline $\begin{array}{l}\text { CON-03 Broad scale of complements } \\
\text { F5-PLAY } \\
\text { Playfulness }\end{array}$ & 0.873 & 2.02 & 1.711 & $0.822 * *$ & $\begin{array}{l}1,106 \\
(5.0 \%)\end{array}$ \\
\hline Entertainment important & 0.817 & 2.34 & 1.640 & $0.864 * *$ & \\
\hline CON-04 More gossip columns & 0.873 & 2.02 & 1.711 & $0.876^{* *}$ & \\
\hline $\begin{array}{l}\text { F6-FREE } \\
\text { Free offerings }\end{array}$ & & & & & $\begin{array}{l}1,011 \\
(4.6 \%)\end{array}$ \\
\hline U-05 Free news service & 0.845 & 4.04 & 1.753 & $0.863 * *$ & \\
\hline U-07 Interesting headlines available & 0.707 & 3.69 & 1.714 & $0.856^{* *}$ & \\
\hline
\end{tabular}

** Correlation is significant at the 0.01 level 